\title{
FERMT3 Gene
}

National Cancer Institute

\section{Source}

National Cancer Institute. FERMT3 Gene. NCI Thesaurus. Code C117075.

This gene plays a role in cell adhesion in hematopoietic cells. 